\title{
SYMBOLISM USED IN SIKKA KROWE'S WEDDING CEREMONY OF MAUMERE, EAST NUSA TENGGARA
}

\author{
Anselmus Teng \\ Department of Language and Literature, Faculty of Language and Literature \\ Kanjuruhan University of Malang \\ Jln. S. Supriadi No. 48 Malang, Jawa Timur 65148, Indonesia \\ Phone : $085749541997 \quad$ E-mail : anselteng17@gmail.com \\ Rusfandi \\ Department of Language and Literature, Faculty of Language and Literature \\ Kanjuruhan University of Malang \\ Jln. S. Supriadi No. 48 Malang, Jawa Timur 65148, Indonesia \\ Phone : $082244655115 \quad$ E-mail : r.rusfandi@yahoo.com \\ Trisno Tunggal Rahayu Wilujeng \\ Department of Language and Literature, Faculty of Language and Literature \\ Kanjuruhan University of Malang \\ Jln. S. Supriadi No. 48 Malang, Jawa Timur 65148, Indonesia \\ Phone : $085791979900 \quad$ E-mail : trisnotrw@gmail.com
}

\begin{abstract}
A symbol is an object that represents an idea, image, visual, belief, action, or material. They are used to convey ideas and beliefs. This means symbol can give the direction for those in choosing certain tools that are used to get their mission. Here, symbol is the expression of a thing that cannot be signed with the right sign. Symbols are alive as long as they have the meanings. Every place in Indonesia has its own culture. One of them is Sikka Krowe's culture of Maumere, East Nusa Tenggara. Sikka Krowe is the special call for one of the ethnic groups in Maumere. It is in Sikka regency area. Sikka itself is the name that refers to a small traditional village known as Sikka Natar (Kampung Sikka). Krowe refers to people in countryside from Nele (west of Sikka regency) to Tanah Ai (east of Sikka regency). Therefore, the researcher is interested in studying this culture in debt by formulating three research questions: (1) How is the procedure of Sikka Krowe's weding ceremony of Maumere. (2) what kinds of symbols used in Sikka Krowe's wedding ceremony of Maumere? (3) What are the meaning of those symbols?. The researcher found the kinds of symbols that are revealed in Sikka Krowe's wedding ceremony like in daily life such as wua ta'a, tua/moke/arak, manu ama and manu muhun, wair hu'er, bala, mu'u, kalar gelang, jarang, tudi, wawi ireng,reng-reng, utan, kila, pagat uma, bolo plagar and lensu widin tilun. . This is the symbol of the simplicity of life. The process of wedding ceremony requires some conditions regulated and set by the norms and traditions.
\end{abstract}

Key words : Symbolism, Sikka Krowe, Wedding Ceremony 


\section{Introduction}

Nowadays, culture plays many big roles in our daily life. It provides a series of pattern by which biological and socio-cultural demands of group members are met e.g. food, shelter, and reproduction and relationship with group and individuals. In this case, people cannot be separated with his group or community. It provides a set of rules to ensure co-operation of the individuals of a group in adjusting environmental situation. Koentjoroningrat (1985: 180) states "culture is about the whole concept, action, and human's work in the society life that be owned by human beings from learning". It means that culture helps in understanding and predicting the human behavior and also provides channels of interaction for individuals within the group. It provides us a guidepost or kind of map for all our life activities. It defines the pattern of behavior for individuals so that people act according to the behavior pattern prescribed and defined by culture.

A symbol is an object that represents an idea, image, visual, belief, action, or material. Symbols take the form of words, sounds, gestures, or visual images. They are used to convey ideas and beliefs. A symbol means more than it literally says. For example, a red octagon may be a symbol for "STOP". On a map, a picture of a tent might represent a campsite. Numerals are symbols for numbers. Alphabetic letters are symbols for sounds. Personal names are symbols representing individuals. A red rose symbolizes love and compassion. Brown (1979) explains that the act of ritual disclose symbol, so the analysis of ritual should be directed on symbols. In here we know that these symbols are one of the main parts of a ritual because it can store the meaning of behaviour or action in a typical ritual of ceremonies.

Sikka Krowe is the special call for one of the ethnic groups in Maumere. It is in Sikka regency area. Sikka itself is the name that refers to a small traditional village known as Sikka Natar (Kampung Sikka). Krowe refers to people in countryside from Nele (west of Sikka regency) to Tanah Ai (east of Sikka regency). Wedding ceremony in Sikka Krowe's culture is very interesting because of its procedures and the symbols that revealed in it. The tradition of Ro'a Mu'u (Potong Pisang) in Sikka Krowe's wedding ceremony for example, is very unique. This ritual is held for welcoming the groom and the bride before they enter their bedroom (called Tama Ola Uneng). Mu'u (pisang) refers to the true happiness of the bridegroom. This is the symbol of the simplicity of life. The process of wedding ceremony requires some conditions regulated and set by the norms and traditions.

\section{Literary Review \\ Relationship Between Language and Culture}

The relation between language and culture is about the structure of the language determines the way in which speakers of that language view world. A somewhat weaker version is that the structure does not determine the world view but is still extremely infuntial in predisposing speaker of language toward adopting a particular world-view (Ronald 1998). 
Some people say that language is the mirror of culture, in the sense that people can see a culture through its language. Another metaphor used to symbolize language and culture is the iceberg. The visible part is the language, with a small part of culture; the greater part, lying hidden beneath the surface, is the invisible aspect of culture. This author's understanding of language and culture is conveyed through the following three new metaphors.

From a philosophical view: language + culture $\rightarrow$ living organism

\section{flesh blood}

Language and culture makes a living organism; language is flesh, and culture is blood. Without culture, language would be dead; without language, culture would have no shape.

\section{The Relationship Between Symbol and Culture}

To the human mind, symbols are cultural representations of reality. Every culture has its own set of symbols associated with different experiences and perceptions. Thus, as a representation, a symbol's meaning is neither instinctive nor automatic. The culture's members must interpret and over time reinterpret the symbol. Symbols occur in different forms: verbal or nonverbal, written or unwritten. They can be anything that conveys a meaning, such as words on the page, drawings, pictures, and gestures. Clothing, homes, cars, and other consumer items are symbols that imply a certain level of social status.

\section{Symbolism and Its Classification}

In literature symbol is generally devided into three parts. They are natural symbol, private symbol, and conventional symbol.

1. Private Symbol, private symbol is a symbol which has subjective meaning based on individual intrepretation. Abrahams (1981: 195) states "private symbols are esoteric and largely unintelligible expect to those whom the author or that author's critics and intrepreter have succeded in educating". People have their own intrepretation in giving the meaning of a symbol.

2. Natural Symbol, Carpenter (1974:71) states " natural symbol is words or images that suggest their meanings. This means symbols has no subjective meaning based on individual intrepretation.

3. Conventional Symbol, Abrahams (1970:195) says "conventional or public symbol is thus "the cross", 'the red, white, and blue', 'the good sheperd', are terms that signify symbolic objects of which further significance is fixed.

\section{Symbolism / Symbols and Meaning} Stein (2008:73) says "a symbol is something that represents an idea, a process, or a physical entity". This means the purpose of a symbol is to communicate meaning. The idea of symbols has been discussed in the center of the development of analytical thought for many years.

\section{Wedding Ceremony}

A wedding is a ceremony where two people are united in marriage. Wedding traditions and customs vary greatly between cultures, ethnic groups, religions, countries, and 
social classes. Most wedding ceremonies involve an exchange of wedding vows by the couple, presentation of a gift (offering, ring(s), symbolic item, flowers, money), and a public proclamation of marriage by an authority figure or leader. Special wedding garments are often worn, and the ceremony is sometimes followed by a wedding reception. Music, poetry, prayers or readings from religious texts or literature are also commonly incorporated into the ceremony.

\section{The Use of Symbols in Wedding Ceremony}

The act of marriage is full of symbolism. It marks the essential union between male and female to create a nurture new life. The symbolism of wedding customs is shown in the wedding ring, joining of hands, and the presence of small children around the bride. The children are a form of sympathetic magic, and symbolize future children. The custom of throwing grain, rice, or confetti is another fertility symbol. Even the wedding cake can be seen as a fertility symbol, as food is often used as a sexual symbol. The custom of breaking a glass or other small object at the wedding reception has sexual overtones, too, as it symbolizes the consummation of the marriage.

\section{Research Methodology}

This study uses descriptive qualitative method. Qualitative research is based on a naturalistic research, ethnography research, case research, and analysis research. It views reality as multilayered, interactive, and a shared social experience interpreted by individuals. Most of description and interpretation are portrayed with words rather than numbers. Based on the intention of this study, the researcher tries to get the description of concepts behind the symbols found in that wedding ceremony of Maumere. This study will consist of findings that are needed to be explained in detail from many sides to know the meanings of those symbols. In this case, the researcher tries to explore cultural phenomenon where the researcher observes the society from the point of view of the subject of study. The cultural phenomenon that researcher wants to share is about wedding ceremony of Sikka Krowe and the use of symbols in that wedding ceremony.

\section{Data and Source of the Data}

The sources of the data are taken from some of relevant data that support the analysis. The data to be analyzed are gathered from two sources. The primmary source is from the wedding ceremony itself which is to prove that there are symbols found in Sikka Krowe's wedding ceremony. The study is completed in the form of the procedures and the symbols which appear in that ritual wedding ceremony. In additional, the other source includes many appropriate documents in the form of theory, literary books, encyclopedia, and internet dictionaries. In this part, the research reads some books and other references which are concerned with the culture in Krowe society specifically about wedding ceremony.

\section{Instrumentation}


For collecting the data, the researcher used three kinds instrumentations are as follows :

\section{Observation}

Generally, the use of observation by the observer is one of ways to obtain the data. At this part the researcher becomes the participants of the research in passive participants of the procession of Sikka Krowe's wedding ceremony.

\section{Documentation}

Documentation is used in this study by the researcher in collecting the data. The researcher uses documentation in his research to record the procedures of Sikka Krowe's wedding ceremony. The researcher records the ceremony by using camera and video from the first steps until the last steps. The researcher enters and follows the prossesion of the ritual of Sikka Krowe's wedding ceremony. The camera and video are used to help researcher in analysing the data.

\section{Interview}

Interviews are a standard part of qualitative research. The qualitative research interview seeks to describe and the meanings of central themes in the life world of the subjects. The main task in interviewing is to understand the meaning of what the informants say. And this research, the researcher makes an interview directly with informants to get the accurate data. Informants here are pople who are having relation with the culture in Sikka Krowe. For example tanah puang (a person who really understands about Krowe's culture)

\section{Data Collection}

Data collection is the process of gathering and measuring information on variables of interest, in an established systematic fashion that enables one to answer stated research questions. The following are the procedures of collecting the data in this study.

1. The researcher asks permission to the couple who will get married to come on their ritual wedding ceremony.

2. The researcher follows the procession from the first step until the last step of wedding ceremony.

3. After that, the researcher documents every step of the wedding ceremony procession by using camera/video.

4. The researcher does the interview with the informants to get the specific information related with symbols meaning that are used in wedding ceremony procession.

5. After interviewing, the researcher summarises that information and tabulates the kinds of symbols and their meaning.

The procedures of collecting the data can be drawn as follows: 


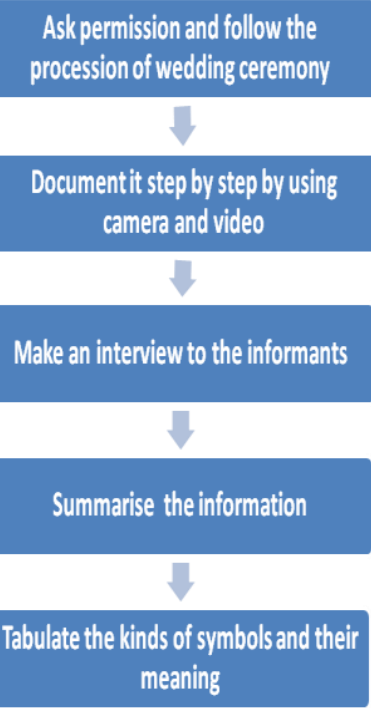

Table 3.1 Data Collection Diagram

\section{Technique of Data Validation (Triangulation)}

Triangulation refers to the use of more than one approach to the investigation of a research question in order to enhance confidence in the ensuing findings. Gliner (1994) described triangulation as a method of highest priority in determining internal validity in qualitative research. The term triangulation stands for the procedure that entails carrying out three measurements to determine the exact position of a point in the landscape. After collecting the data, the researcher discusses with his friends about the datum that are appropriate related with the source. He does it in order to get the different ideas or opinions which help him to expand his mind. After that, he consults the data with the expert, $\mathrm{Mr}$. Adrianus Janiku.

\section{Data Analysis}

Data analysis is very important in every observation and interview because it is organized to rub with the data in design, category, and the unity base analysis. The function of data analysis is to know the result of the interview. After collecting the data, the researcher takes some steps below in the data analysis.

Steps on analyzing the findings can be drawn as follows:

1. Tabulating the kinds of symbols and their meaning.

2. Triangulating the data to the expert.

3. Checking the data with the sources.

4. Drawing the conclusion from the whole data analysis.

\section{Research Findings}

The following sections describe the processes of customary marriage usually happens in Sikka Krowe society. The descriptions include before, during, and after the marriage procession. The presented information was received from informants interviewed by the researcher. In addition, the researcher also found the information from the relevant sources such as books and the internet.

\section{A. Selection of Dating}

Before marriage takes place, perents sometimes focus only on the old traditions to choose a mate for their child. On the other side, nowadays this is no longer found in Sikka Krowe society. The nature of the selection of a mate in ancient times, is often done because parents want their child to be able to marry a good person. Therefore, before making a decision to their child's mate, perents must first hold a vote to women who will be married. This assessment is done by the parents, but the role of the relatives is also crucial. There are several consideration for 
the assessment including beauty, descent, good in religion, wealth, manners, and moral. If a man intends to get married, he usually negotiates in advance with parents and relatives.

$B$. The engagement period

In some regions, the sign of proposal can be: betel nut, a sum of money (dowry, customary money), cooked foods, fabrics, jewelry, plantation and so on. The sign of this proposal is submitted by the spokesman of the man to those who proposed by the costums proverbs and language which beautiful, polite, courteous, and respectful to introduce the members of the group who come, one by one kinship with the groom. Similarly, a spokesman of the woman who proposed would declare its acceptance by the indigenous language and proverbs.

Before the proposal is known by his family, the man has taken the following steps:

\section{a. Briu-Mikut}

Briu-Mikut is introduction. It can happen anywhere like in wells, market, garden, on the home from church, and other places. The meeting is disclosed in the form of rhyme usual custom, which reads:

Uneng ora ganu mude

Ganu mude 'uneng rua

Kokong ora ganu pau

Ganu pau parang beda

Nyong ga'i nyonya grengang

Bopo reta wair matang

Bopo loa lopa leba

Ulit lusi hama-hama

Wulang nilo tukeng

Pano 'abang mude mi

Mude 'ata jaga gahu

Poi ni'a bano walong

Gopi roing guung bledot

'Odo heret lami lurung

Lurung heret 'ekeng-tet
Nyong heruk taang-tot

The english translation of the poem above is given below :

I have dreamed

Like I dreamed a lemon

Lemon which devided into two

parts

I have loved

It looks like a manggo

A manggo which is already to eat

I like you and you do the same

Wash the clothes in the river

It does not mean that we should

not open our clothes

The same pure skin

Like a moon in the night

Walk to get the sweet lemon

A lemon which is protected by its owners

Just look and then go away

You look like a yellow soup

Yellow soup that is sweet

I taste it with great pleasure

Gestures and behavior of the young man while singing the traditional rhyme itself will be followed by the family, and it is advised to them to move to the next step for wedding.

\section{b. Diri Miping/Miping}

Diri mipin means a man sees his candidate of wife in his dream. This refers to the girl, he is going to get married with. The expression of Diri miping is like the following statements:

Ra'ik au ga'i beta waing

Niat 'waung naha plaha oti oha

Dadi miping ia hagongwohong

Sape tana 'inga salang

Gu reta ma gou wua reta lekong pitu

Rape dekak nora 'linang

Gu lau lema lepo beta waing

Ra'ik au ga'i herong meng 
Lero wawa naha sorong oti loni

Badi blawong ia kiring rena

Sape niat eh poa

Gu reta ma bata taa reta lemang

walu

Mata taa nora wuing

Gu lau 'rawit woga herong meng

Gu wua 'udek ganu waing

Taa pahar ganu meng

The english translation of the statement above is the following.

If someone wants to be married

Spread out the bed and the pillow

in the night

Dream the person you love

And when morning is broken

Go and get the seven or eight stem

of betel nut

Then bring these to that house

As the proof of the engagement

As the important note in Sikka Krowe beliefs, a good dream is when we see a piece of palm with the dense of fruit and that palm trees are growing in the yard.

\section{c. Kula Babong}

After doing diri miping, the dream will be told by a man to his family. Then they will be invited to analyze and discuss that dream that contains of the girl's family level, the health, and the skills who will be married by the men. The results of the negotiation will be agreed by the man's family by sending Aa Gete 'Pano' Ahu/"Ahu Wating" (aunt/uncle) to the girl's house.

\section{d. Pano 'Ahu /' Ahu Wating}

The next stage is Pano 'Ahu/'Ahu Wating. The customary process will begin when Aa Gete (man's aunt) is going to choose the change to come to the house of the girl. She will talk with that girl about the man who want to marry her. She told her brother to the girl about his skills, and assured that her brother would match the girl. Thus that girl will be easy to communicate with the aunt. Then the aunt begins to sing traditional rhymes as follows:

\section{Mitang lentok-lentok \\ Ganu pajung wawa jawa \\ Bura bleler-bleler \\ Ganu bei reta kongas \\ Telo temang ha \\ Ela tana wige rua \\ Nong mitang nona heret \\ Ganu dala nora wulang}

The english translation of the poem above is:

The black sweet girl

Like a javanese umbrella

White and soft

Like bei in Kongas

An egg

Falls down into the ground and breaks into two parts

The sweetgirl I dreamed

Like a star and a moon

\section{e. Wua Taa Oko-Kape}

In the process of Wua Taa OkoKape, the aunt will come again with two or three male of her family members carrying betel-nut in the container, ripe bananas and pastries, and fruit towards the girl's house. Here there will be a short time but very meaningful dialogue. The aunt will answer in the form of traditional figurative: "your brother in law sents me to give you the good news". This allusion is understood by mothers or female representatives and they will answer: "Let us be heard directly from herself in question". 
The girl will be called by her parents and to deliver the news. Shyly, she nods and smiles as a sign of an agreement. After knowing the answer, all the goods carried by the men handed over to the woman's family. The girl will be given a bit of money as her pocket money. When they want to go back, the girl's mother usually will convey the message that they have received the goods provided by the men. After going home, the aunt will report to the man's family and they will negotiate to set a schedule of "prage wae, ara mata" (proposing to a girl).

\section{f.Prage Wae Ara Mata}

Prage wae ara mata is the stage of the formal relationship ceremony between men and woman. At the agreed time, the delegation of man come with 2 bottles of wine (Moke) and two hens which are followed by betel nut, tobacco and side dishes to eat while talks. People from the woman side ("ina-'ama") will give a greeting in front of their house by saying: "reta une, ami lema ko lohor?" (can we come into your house?). The woman who is still in the house will answer: "uhe die dang hading" (The door is opened, the stairs attached). The family of man will enter into the house by the greeting: Lopa hidi lepe, wenang pahar (be careful).

After a welcome to eat betel nut and smoking while serving traditional drinks, the starting of the important event will be opened by party delegates "ina-ama" (female). Then "me wari" (man's side) will ask the form of the proposed budget to inaama (girl's side). If the budget (bride price) is too high, the parties of $m e$ wai may negotiate to get simplification until they get an agreement.

Before they returned, "ina-ama" will give suggestion that the day after tomorrow me wai will give them a piece of ivory or a sum of money as the evidence of engagement has officially expressed "pete mateng" or "wua udek taa pahar" or "muи tukeng bewu ruing".

\section{g. Wua Taa Wa Gete /Kila Jarang/Seneng Bura Kirek}

At the stage of Wua Taa Wa Gete / Kila Jarang Seneng Bura Kirek me wai party, the man's family will come again with the large members while bringing horses, ivory, betel nut in a large container filled ring therein and the amount of money tied up and wrapped around with a strong thread rope. The delegation of man's party also bring foods such as rice, corn, bananas, chicken, fish, and coconuts in large quantities. Up in front of the house ina ama, the door will be closed. From the yard they will exclaim: reta une ami lema ko lohor? Family of girl in the home would answer: whe in dang hading. The two sides will hold talks to resolve the dowry (bride price) that will be brought in. After that, the group will be treated by eating and drinking until satisfied.

The girl will also give reward as an honor to the man. The rewad can be rice, two big pigs, Moke (wine), traditional cake and utan (sarong) for woman who is participating as part of man.

\section{Wedding Ceremony}

In the pre-wedding, both bride and groom have to keep manner, gestures, behavior and social life and psychological maturity to enter a new 
household. If one party wants to travel far to take more than one week, then he or she must report it to the other party. So that the relationship is getting closer with the purpose of knowing each other deeply. In certain cases, engagement is canceled because it is discovered things that are unwanted by one party.

When it is time to get married, the process will be passed as follows:

a. Hakeng Kawit (determining the wedding schedule)

According to the schedule agreed upon, then the spokesman of me wai while bringing a bottle of moke (wine) and manu rua (two hens) will negotiate about the right time to get married in the girl's home. In the talk, the scheduled for a day reading the names on the church will also be discussed. Furthermore, both sides make preparations to "wai-sea" (pounding rice) for weddings and also make traditional cakes (bolo plagar, kolomoe).

\section{b. A Wija/A Bleba}

A WijalA Bleba is the time when the me wai (male) held a banquet to collect a dowry. In this banquet, there were invited also people who are from the relatives, me wai, and also from friends and acquaintances. This is done as a form of solidarity.

c. Wake 'Unu (the first day of wedding ceremony)

Wake 'Unu is the beginning of the party where each of both families come to gather together in their house. In man's home, there is family who brings dowry, ivory, labu sako, and so on. In summary, it is a party for family gathering. Approximately at 10:00 pm the woman party will go to pick up Aa Gete (family: ancle and aunt) of the man, to prepare the bridal chamber that has been provided.

\section{Married day}

Based on the tradition of the Catholic religion, it is told that the wedding ceremony is made in a simple ceremony in which elderly man would be handed over to the aunt for "plaha oha sorong loni" (time for having discussion in the mat). For families with social strata considered a noble family, his or her marriage ceremony conducted by indigenous elders. According to the agreed time, the groom is accompanied by his family to the house of the bride. Both bride and groom sit on a mat cushions and surrounded by both family. The man will be carried by his family to the girl's house. And then both man and girl siting in the mat surrounded by their family. The socialite with his assistents open the ceremony among them. Then there will be served food and traditional drinks to the bride and groom and all the family.

Advice for men in traditional languages is:

Au mo'ang pramang woga, Buut sai taka nora porong, Mahokot ma dokit, Ma hebo ma kare, Bihing waing ta'ing lopa morung, Naga meng erung lopa luring, Bihing waing to'eng lopa tegor, Naga meng kokor lopa mara, Ra'ik bihing waing to'eng tegor, Odi wai du'a gou le'u utang biha wikir, Gou gawi 'ata dueng, Gou le'u 'ata wuang potat, 'ata lutur wi uur, Ita wae meang ganu mate, Ra'ik bihing meng ta'ing morung, Odi me doi bata le'u kletang beta teok, Bata lewat le'u 'ata hoat, Odi go le'u 'ata 'ubung tobong, 
'ata harang wi leke, Ita mata berat ganu bunu

The english translation of the above advice:

Find out your life in the land or in the sea

And give it to your wife

Bring your machete and ax in the morning for working

Cut down the tree and climb the coconut

Distill the wine to feed your wife and your children

Do not care with negative perseption from others to apart from your family

Your wife is just for you as your responsibility

While counsel for the bride also delivered in the traditional language with the following chant:

Au du'a giit meti lepo, Buut sai buhar nora ehar, Niku mitang lodo lekuk, Lodo wawa dang pu'ang, Taduk touk sai wawa temo 'wau, 'lair beli sai ulit lusi, Ulit lusi lopa biha wikir, Tangar beli sai 'lorang, 'lorang lopa boga ligur, Lobe beli sobeng beli, Mitang naha sidak wa'I, Sapu beli sa'e beli, Merang naha hawing palik, Wiwir loa lopa guring, Watang loa lopa bekang, Odi 'ata to ita wi hoot, 'ata hiri ita wi kengong

The english translation of the above chant:

When the dark comes, it is time to cook, and the food is ready to eat then boild the water for your child and husband
When morning is broken, weaving the sarong for your family, do not care with others who want you apart from your family

Your husband is just for you as your responsibility

After supper is finished, the groom with family go home and wait for the right time until the bride party picks them up that called "tama ola uneng".

\section{a. Tama 'Ola' Uneng}

Tama Ola' Uneng is a ceremony in which for the first time the bridegroom enters the bridal bed, but not at will. When night comes about at $11 \mathrm{pm}$, the groom is picked up by bride's family. The bride is guided by Aa Gete entering to the bed. Then Aa Gete goes out again to lead the groom into the same bed. Aa Gete gives the traditional advice for both:

Au dua baa glit meti lepo, Naha tutur gepu ganu hejung, Ganu hepung tereng 'uneng, Au moang baa mangang pramang woga, Naha harang blewo ganu hewong, Ganu hewong tua wutung, Lopa tutur deteng wawa leang blong, Tilu riwung wawa diri rena, Ita wae meang ganu mate, Lopa harang lasa wawa lasa lawing, Mata ngasung wawa nia ita, Odi mata berat ganu bunu

The english translation of the advice above:

As a good wife, you have to talk frankly, speak softly like the sound of mosquito

As a great husband, you have to talk to others, speak slowly, like when pouring wine in the glass, do not tell your problem to all 
people, they will hear all, you will be ashamed until we die, do not be rude, people will see your act, you will be ashamed,

Then Aa Gete lets the bride and groom into their bridal bed that has been provided while saying, " $d a^{\prime} a$ blewut belung Sape mate ko Loar" (you will never be apart until you die). Meanwhile all people who participate in the procession are served enough food, pitu pigang Makok walu (seven plates and eight bowls) by the bride party. It means each person gets various kinds of food and vegetables. Most of them will get ivory, money, hens, and banana. Then both the bride and groom will come out with Aa Gete, to eat together while drinking Moke and dancing until night.

1. Ritual of Post Wedding Ceremony Ritual post wedding ceremony is devided into 6 parts:

\section{a. Wehak Bunga}

Wehak Bunga ceremony is held early in the morning about at $5 \mathrm{am}$. Aa Gete of the groom with a bundle of flowers comes and knocks on the door. He enters and gives the flowers to the bridegroom as the new family.

\section{b. Tung Temang}

Tung Temang ceremony is a traditional ceremony in which the woman delivers the materials of Tung Temang to the home of the groom which consist of four pigs, one big goat, four sacks of rice, four jars of Moke, four sarongs "diheng", seven sarongs for bridesmaid, traditional cakes and side dishes.

\section{c. Tung Balik}

Tung Balik ceremony is a custom where the groom family gives the brideprice after wedding ceremony. It is happened when tung temang has been done by the female. Because of the experience where the groom party do not deliver the dowry or delay, then many times the woman also delay Tung Temang.

\section{d. $H u^{\prime} i$}

The tradition of $h u^{\prime} i$ (bath) is conducted after four nights when both get married. For four nights, the bride is forbidden to get shower because it will be held the ceremony of "Huler Wair". Both bridal shower at the house, and sit side by side, then both of them are watering by Tanah Puang with "huler wair" while saying: "Kamang blirang wiing Ganu bao, Blatang wiing Ganu wair, Punan daan mosa hug". (hopefully healthyfresh).

\section{e. Tung Lako}

Lako Tung ceremony is held after taking a bath (hu'i). Groom's party comes with delicious foods, as well as the woman together eating and drinking while making a joke, and dances for some hours. In modern times, this custom is not just done at home but also in large rivers while having a picnic with family. That is where they bathe and eat together until the afternoon.

\section{f. Ngoro Remang \\ Ngoro Remang ceremony is a ceremony to demolish the tent outside the house. Ngoro remang price is also mentioned in the brideprice. But it is no longer valid today because it has been replaced together with that party itself. Indeed, the purpose of Ngoro}


remang is the wages of waiters who helped cook in that wedding party.

\section{Wedding in Catholic Church}

Before marriage in the Catholic, the name of the bride and groom were announced three times in the church, to be known by the whole people and can send a message if both partners have or do not have problems in relations with the marriage. The marriage in the Catholic Church led by pastor and of course done in the Church.

The traditional clothing the bride worn is dressed in the style of the Portuguese: Kimang heret (Material soft cloth in yellow), labu nujing (red fabric clothes decorated with flowers), Soking telu (three bun of gold), Kila bahar (gold ring), and Gebe-Wulang Nitang (hair bun). She will be guided by the groom's uncle and accompanied by all the family. $\mathrm{He}$ is accompanied by a second-inlaw and sisters who brought flowers, yellow rice, as well as his family.

For the ceremony in the church performed according to church liturgy sung by the priest and the two guardians who become witnesses. After the religious ceremony, the bride and groom families accompany the two sides towards the bride's house. When the bride arrived at the front of the house, an old custom picked flowers with yellow rice and spead it to the bride and groom along with the greeting: wuat naha baka lika (be a new life in your new family). Both the bride and groom come into the house to greet their parents by saying: Mai hugu ri'i inang limang, Mai kongong gapu' Amang wa'ing (Humble themselves before their parents, kiss and embrace them deeply).
E. Kinds of Symbols Used in Sikka Krowe's Wedding Ceremony of Maumere and Their Meanings

The following sections describe the kinds of symbols used in Sikka Krowe's wedding ceremony and their meanings. The presented information was collected from the documentation of the wedding procession and the interview from the informants to get the valid data.

Symbols that are used in wedding ceremony are:

1. Wua Ta'a (betelnut/ siri pinang)

Long time ago, Krowe people always gathered together in their family to eat wua ta'a as a habit to clean their teeth because there was no toothpaste at that time. It is like a unique tradition and still exist until now. This tradition brings a big effect to Krowe society. People in Sikka regency especially for the elders still like to eat wua ta'a everyday. Nowadays in Krowe culture, wua ta'a is used as the symbol of an agreement between the bride party and the groom party in build a new family or relationship before they are going to be married. The groom's family will bring wua ta'a again in wedding ceremony procession to show to people that there will be happened a wedding party because both relatives of bridegroom have agreed to be one family.

\section{Tua (wine/arak)}

Although in most regions, arak is forbiden to consume but in Sikka Krowe, it is a traditional drink. It seems like a crazy habit but it is the reality that is practiced by Krowe society. People like to drink moke because by doing this way, they can make many friends easily. It simbolyzes togetherness and sociality. 
In wedding ceremony, the bridegroom's party must supply moke to people (men) who attend the wedding ceremony procession. This is the unique tradition that Krowe society have to keep as a part of their culture.

\section{3. Мапи ama, manu muhun (cock and hen)}

Aa gete (aunt and uncle of the groom) bring 'manu ama' and 'manu muhun' to the bridegroom a day after the process of wake 'unu was happened. It simbolyzes a couple who are going to be married.

\section{Wair Hu'er}

It is a bowl of water for blessing the bridegroom. This tool is used by the elder/ Aa getel socialite for spattering the bridegroom with water in it while saying traditional poem as usual. It is happened when the bridegroom are on their way from the church before entering the house. It means both of them are blessed and protected from every evil before entering to their new house. It simbolyses the goodness.

\section{Bala (ivory)}

Bala is the central prideprice in Krowe culture. It is like a fixed price that must be given to the bride's party. It simbolyzes the highest honorary to the girl as the prince and mother.

\section{6. $М u^{\prime} u$ (banana)}

$M u ' u$ is one part of the prideprice. The bridegroom party brings $m u$ ' $u$ in large number to the one party. Krowe society believe that it is the symbol of the simplicity of life. Eating this $m u^{\prime} u$ means that we are not rich enough but we still have something to eat.

\section{Kalar Gelang}

It is a set of bracelet that is made from ivory (bala). The bride usually uses 'kalar gelang' when she is still on the process of wedding ceremony. It is a traditional way for Krowe society in giving the honorary to a wife. It is the symbol that a girl has been a wife and a mother.

\section{Jarang (horse)}

The groom party brings some horses (it can be more than 10 horses as usual) to the bride's party as the part of big brideprice. Generally people ride horses for transportation or trading from one place to other places. It is the symbol of manlineness.

\section{Tudi (knife)}

The groom's party gives 'tudi' to the bride's party in the process of 'prage wae ara mata' that has been explained before. It is the symbol of the honorary to ina ama (bride family). This tool is not for sale but it must be kept as an inheritance because it will be used again for the next wedding ceremony.

\section{Wawi Ireng (big pig)}

The bride's party gives the groom's party enough brideprice as the response. One of that is 'wawi ireng'. It is the symbol of the honorary to the groom's family.

\section{Lensu Widing tilun}

The groom always uses 'lensu widin tilun' in wedding ceremony as the clothes custom (for men). It the symbol of a king because it is a greatness Krowe culture. it is usually used by men in celebrating culture events. 


\section{Utan (sarong)}

Generally, Utan is the traditional sarong from Sikka society. All Krowe people especially the mothers use this sarong to cover their body from the cold. In other case, they also use this sarong as the brideprice and a gift in wedding ceremony or in other customary events. It simbolyzes the motherhood. A woman who is wearning this traditional sarong always looks like a mother and beautiful.

\section{Reng-Reng}

Reng-reng is a pair of tools bound in the feet usually used by a man when he is dancing together with the women to greet the bridegroom after following the procession in the church. It is used to harmonize the sound between the traditional dance (called Hegong Dance) and the dancers.

\section{Pagat Uma (Hut Decoration)}

Pagat uma is made by the groom's party that consist of corn, rice, sarong, and two hens in the top. It is given to the bride's party in the process of wua ta'a wa gete/kila jarang/seneng bura kirek.Krowe society believe that it symbolyzes a sacrifice to the God to make the bridegroom for being a happy family.

\section{Kila (Ring)}

Generally, a pair ring is known as the unity in a wedding ceremony. The couple with the ring in their hands emphasizes that both of them cannot be apart until they die. People especially Krowe society believe that it simbolyzes the unity.

\section{Discussion}

The customary marriage in Sikka Krowe's wedding ceremony is devided into three parts. There are pre wedding ceremony, wedding ceremony, and post wedding cremony. Every part in the procedure of customary marriage has its own purpose. In this era,some people do not follow the right procedure of customary marriage like what researcher has explained before. For example, when a man wants to marry a woman, he directly told the woman he loved to his family. Then his family will discuss it called ' $k$ ula babong' and then they will continue to the process of 'prage wae ara mata'. It does not mean that they do the wrong way in the procedure of customary marriage in Sikka Krowe's culture. The basic reason is sometimes some of their relatives come from another places that are very far from the bridegroom's house. In other cases, a woman who is pregnant before getting married also will not follow the customarry marriage procedures as usual.

Generally, every local customs in every places in Indonesia is very different between one another. This statement means that symbols used in Sikka Krowe's wedding ceremony of Maumere is different with symbols used in wedding ceremony in other places like Kalimantan, Java, Sumatera, etc. For example, moke (wine/arak) is the forbiden drink to consume in most regions, but it is a traditional drink in Krowe culture. It simbolyzes togetherness and solidarity. It makes Indonesia becomes a country with thousands of culture. 


\section{Conclusion}

The customary marriage in Krowe culture is a custom of Krowe society that consists of three parts. There are before, during, and after wedding ceremony. The process before wedding ceremony consists of Briu Mikut,Diri Miping, Kula babong, Pano ahu/Ahu Wating, Wua Ta'a Oko Kape, Praga Wae Ara Mata, and Wua $T a ' a W a$ Gete. Besides, the process during wedding ceremony consisits of Kela Narang, A Wija/A Bleba, Wake 'Unu, Paha Oha Sorong Loni, and Tama Ola Uneng. And the last process of Sikka Krowe's wedding ceremony consists of Wehak Bunga, Tung Temang, Tung Balik, Hu'i, Tung Lako, and Ngoro Remang. Every step of these process of that wedding ceremony has the tradition rule. Wedding ceremony in Sikka Krowe's culture is very interesting because of its procedures and the symbols that revealed in it.

Meanwhile symbols that are used in Sikka Krowe's wedding ceremony of Maumere are reflected on tools, animals, and the means of livelihood of Krowe's culture. The symbols are like: Wua Ta'a (betelnut) as the symbol of an agreement; Tua (wine/arak) that simbolyzes togetherness and sociality; Manu ama, manu muhun (cock and hen) that simbolyzes a couple who are going to be married; Wair Hu'er that simbolyzes the goodness; Bala (ivory) that simbolyzes the highest honorary to the girl as the prince and mother; $M u$ 'u (banana) as the symbol of the simplicity of life; Kalar Gelang as the symbol that a girl has been a wife and a mother; Jarang (hourse) as the symbol of manlineness; Tudi (knife) as the symbol of the honorary to ina ama (bride family); Wawi Ireng (big pig) as the symbol of the honorary to the groom's family; Lensu Widing tilun as the symbol of a king, it is a greatness Krowe culture.

\section{Suggestion}

The results of this research do not cover all about the process of Sikka's Krowe wedding ceremony, the symbols and their meaning. For this reason, this is still far from the complete, but this study just provides several symbols used in the process of wedding ceremony in Sikka Krowe of Maumere. The researcher suggests that the readers who want to analyze symbols can add the theory from other sources which are not only included in this research but also from other references.

This researcher suggests to community organization in order to maintain this kind of culture, the tradition of Sikka Krowe's wedding ceremony enforced so far. The researcher hopes that this kind of process of wedding ceremony of Sikka's Krowe is not eliminated by the rapid development of the age and affect people's live. In addition, the researcher suggests for the next researchers to conduct further research with different research problems but still dealing with symbols used in Sikka Krowe Community. The researcher also hopes that further researchers could continue this research by interesting the issue of symbolism used in Sikka Wedding Ceremony more deeply. By doing this, better understanding about symbols used in Sikka Krowe Wedding ceremony will be revealed. The results are also important to the students of Kanjuruhan University 
because these result can give them better understanding about cultural and pragmatics issues. This understanding can then be used as reference for further study. 


\section{References}

Abraham, M. H. (1981) . A Glosary of Literary Terms.

Brown, P. (1994) "Society and the Supernatural: a Medieval Change." Deadalus, Spring, Pp 133-147.

Carpenter, J \& Peter Nr. (1974) . Element of fiction.

Gliner, M. D \& Brauer, M., J, C. M. (1994-1995). The effects of repeated expressions on attitude polarization during group discussions. Journal of Personality and Social Psychology.

Koentjoroningrat. (1985-180). Aspek Manusia dalam Penelitian Masyarakat (bersama Donald K. Emerson), 1985. Jakarta: Kerjasama Yayasan Obor Indonesia dengan PT Gramedia

Ronald. (1998). Language Handbook. Washington, DC: Georgetown University Press.

Stein. (2008). Symbols and their function in manageing the anxiety of change. International Journal of Psychoanalysis 81, anxiety of change. International Journal of Psychoanalysis 69. 